Data on 76 Patients evaluated in Trial

\begin{tabular}{|c|c|c|c|c|c|c|c|c|c|c|c|c|c|c|c|c|}
\hline & \multicolumn{4}{|c|}{$\begin{array}{c}\text { Age } \\
\text { (Years) }\end{array}$} & \multicolumn{4}{|c|}{ Years after Menopause } & \multicolumn{5}{|c|}{$\begin{array}{c}\text { Disease-free Interval } \\
\text { (Months) }\end{array}$} & \multicolumn{3}{|c|}{$\begin{array}{c}\text { Dominant Site of Lesions } \\
\text { (No. of Patients) }\end{array}$} \\
\hline & $\begin{array}{c}\text { No. of } \\
\text { Patients }\end{array}$ & Mean & Median & Range & $\begin{array}{l}\text { No. of } \\
\text { Patients }\end{array}$ & Mean & Median & Range & $\begin{array}{l}\text { No. of } \\
\text { Patients }\end{array}$ & Mean & Median & Range & $\begin{array}{c}\text { No. with } \\
\text { No } \\
\text { Interval }\end{array}$ & $\begin{array}{c}\text { Soft } \\
\text { Tissues } \\
\end{array}$ & Osseous & Visceral \\
\hline $\begin{array}{l}\text { Nafoxidine } \\
\text { L-Dopa }\end{array}$ & $\begin{array}{l}36 \\
40\end{array}$ & $\begin{array}{l}61 \cdot 4 \\
64 \cdot 8\end{array}$ & $\begin{array}{l}64 \\
65\end{array}$ & $\begin{array}{l}39-76 \\
49-81\end{array}$ & $\begin{array}{l}36 \\
40\end{array}$ & $\begin{array}{l}13 \cdot 8 \\
15 \cdot 9\end{array}$ & $\begin{array}{l}15 \\
16\end{array}$ & $\begin{array}{l}2-31 \\
2-46\end{array}$ & $\begin{array}{l}27 \\
33\end{array}$ & $\begin{array}{l}23 \cdot 2 \\
47 \cdot 1\end{array}$ & $\begin{array}{l}22 \\
29\end{array}$ & $\begin{array}{l}4-92 \\
4-165\end{array}$ & $\begin{array}{l}9 \\
7\end{array}$ & $\begin{array}{l}9 \\
6\end{array}$ & $\begin{array}{r}11 \\
6\end{array}$ & $\begin{array}{l}16 \\
28\end{array}$ \\
\hline
\end{tabular}

reviewed independently. To our knowledge these small series have not been expanded and in at least one of them no new remission has been obtained. ${ }^{18}$

We did not expect to obtain remissions from $\mathrm{L}$-dopa because it is a poor inhibitor of prolactin secretion. Rozencweig et al. ${ }^{10}$ showed that L-dopa produced a saw-tooth effect on blood prolactin levels, with decreases followed by large rebounds. Bromocriptine (CB 154), however, steadily depressed the blood prolactin level down to $25 \%$ of the pretreatment level in postmenopausal women. ${ }^{10}$ Yet bromocriptine also failed to produce a single case of remission of breast cancer. ${ }^{19}$ If prolactin suppression were therapeutically effective in breast cancer favourable results would be expected from bromocriptine rather than from L-dopa. Indeed, if convincing evidence should be produced showing breast cancer regression under L-dopa treatment other mechanisms than prolactin suppression should be looked for

Do the negative results with L-dopa and bromocriptine rule out any influence of endogenous prolactin on the maintenance of breast cancer growth ? Extreme caution is needed in answering this question because none of these drugs can suppress totally the blood prolactin. ${ }^{10}$ For a definitive answer more potent drugs must become available. Obviously, these results do not exclude the possibility that prolactin might be a key factor in breast carcinogenesis or very early stages of breast cancer development, as suggested by observations in animal models and by the recent report of Kwa et $a l .5$

This study was made by one of the co-operative groups of the
European Organization for Research on Treatment of Cancer (E.O.R.T.C.). The chairman was J. C. Heuson, secretary W. H. Mattheiem, representative of the E.O.R.T.C. council H. J. Tagnon, and co-ordinator $M$. Staquet.

We thank Dr. S. K. Carter, National Cancer Institute, Bethesda, U.S.A., who supplied nafoxidine.

\section{References}

1 Boot, L. M., Induction by Prolactin of Mammary Tumours in Mice. Amsterdam, Noord-Holland Publishing Company, 1969.

${ }^{2}$ Boot, L. M., International fournal of Cancer, 1970, 5, 167.

3 Pearson, O. H., et al., Transactions of the Association of American Physicians, $1969,82,225$.

4 Heuson, J. C., et al., Gynecological Investigation, 1971/72, 2, 130.

5 Kwa, H. G., et al., Lancet, 1974, 1, 433.

Heuson, J. C., in Mammary Cancer and Neuroendocrine Therapy, ed. B. A. Stoll, p. 349. London, Butterworth and Co. Ltd., 1974.

${ }^{7}$ Malarkey, W. B., Jacobs, L. S., and Daughaday, W. H., New England Fournal of Medicine, 1971, 255, 1160.

${ }^{8}$ Kleinberg, O. L., Noel, G. L., and Frantz, A. G., Fournal of Clinical Endocrinology and Metabolism, 1971, 33, 873.

${ }^{9}$ Minton, J. P., and Dickey, R. P., Lancet, 1972, 1, 1069.

10 Rinton, J. P., and Dickey, R. P., Lancet, 1972, 1, 1069.

11 Murray, R. M. L., Mozaffarian, G., and Pearson, O. H., in Prolactin and Carcinogenesis, ed. A. R. Boyns and K. Griffiths, p. 158. Cardiff,

Alpha Omega Alpha, 1972.
12 Frantz, A. G., et al., Clinical Research, 1972, 20, 864.

13 Minton, J. P., Cancer, 1971, 33, 358.

14 Stoll, B. A., Lancet, 1974, 1, 431.

E.O.R.T.C. Breast Cancer Group, European Fournal of Cancer, 1972, 8, 387.

${ }_{16}$ Bloom, H. J. G., and Boesen, E., British Medical fournal, 1974, $2,7$.

17 Heuson, J. C., et al., British Medical fournal, 1975, 2, 711 .

18 Pearson, O. H., personal communication, 1975.

19 E.O.R.T.C. Breast Cancer Group, European fournal of Cancer, 1972, 8, 155.

\title{
Intravenous Treatment with Rimiterol and Salbutamol in Asthma
}

\author{
G. E. MARLIN, PAUL TURNER
}

British Medical fournal, 1975, 2, 715-719

\section{Summary}

The bronchodilating efficacies and $\beta_{2}$-adrenoceptor selectivities of rimiterol $\left(0.2,0 \cdot 1\right.$, and $\left.0.05 \mu \mathrm{g} \mathrm{kg}^{-1} \mathrm{~min}^{-1}\right)$ and salbutamol $\left(0 \cdot 1,0.5\right.$, and $\left.0.025 \mu \mathrm{g} \mathrm{kg}^{-1} \mathrm{~min}^{-1}\right)$, intravenously infused for one hour, were determined in five patients with chronic asthma. Each drug infusion produced and maintained a dose-related improvement in forced expiratory volume in one second $\left(F E V_{1}\right)$. A further increase in $\mathrm{FEV}_{1}$ was produced by inhalation of

Department of Clinical Pharmacology, St. Bartholomew's Hospital, London EC1A 7BE

G. E. MARLIN, M.B., M.R.A.C.P., Research Fellow

PAUL TURNER, M.D., F.R.C.P., Professor the same drug by pressurized aerosol at the end of each infusion, which suggested that no resistance had occurred. Similar dose-related increases in heart rate, pulse pressure, and skeletal muscular tremor were produced by each drug. Peak heart rate increases varied greatly between individuals, ranging from 12 to 30 beats/min with the high doses but always less than 10 beats/min with the low doses of each drug. On rimiterol the heart rate reached equilibrium earlier during the infusions and declined more rapidly after they had stopped, thus providing an accurate means for monitoring dosage.

Rimiterol with its short half life-a desirable property for an intravenous drug with respect to safety-may prove to be a valuable bronchodilator in severe asthma when intravenous infusions are indicated.

\section{Introduction}

Severe asthma, refractory to previous bronchodilator treatment, 
remains a common hospital emergency. Bronchodilators by intravenous infusion and intermittent positive-pressure ventilation (I.P.P.V.), large doses of corticosteroids, oxygen therapy, and physiotherapy are commonly used. ${ }^{1-5}$ Aminophylline, though commonly used for intravenous bronchodilator therapy, often causes nausea, vomiting, tachycardia, and excessive motor stimulation.

Though $\beta_{2}$-adrenoceptor stimulating drugs are widely used by oral, inhalational, and subcutaneous routes, studies of these drugs by the intravenous route have been confined to determining such pharmacological properties as their relative potency and selectivity. ${ }^{6-14}$ Rimiterol hydrobromide is a new shortacting $\beta_{2}$-adrenoceptor stimulating drug similar to salbutamol in $\beta_{2}$-adrenoceptor selectivity when administered by single intravenous injection in man. ${ }^{1-15}$ Our purpose was to determine the bronchodilating efficacies, $\beta_{2}$-adrenoceptor selectivities, and therapeutic dose ranges of rimiterol and salbutamol by prolonged, constant, low dose, intravenous infusions in asthmatic patients.

\section{Patients and Methods}

Five men aged 48-63 years with chronic, stable, partially reversible airways obstruction due to either asthma or chronic bronchitis with asthma ${ }^{16}$ were selected for study. There was no history of atopy among the patients, though one was sensitive to polyurethane. All gave a history of previous cigarette smoking (over 20 cigarettes/day), but none were smoking at the time of the study. The patients were normotensive and had normal electrocardiograms (E.C.G.s) and chest radiographs. All were taking prednisone, beclomethasone diproprionate aerosol $400 \mu \mathrm{g} /$ day, and salbutamol aerosol 200-800 $\mu \mathrm{g} /$ day (table I). Respiratory function before and after a bronchodilator, with predicted normal values, is shown in table II. The informed consent of each patient was obtained.

TABLE I-Sex, Age, Height, Weight, Diagnostic Group, ${ }^{16}$ and Current Medica ${ }^{l}$ Treatment of Five Patient

\begin{tabular}{|c|c|c|c|c|c|c|c|}
\hline \multicolumn{3}{|c|}{$\begin{array}{l}\text { Case } \\
\text { No. }\end{array}$} & $\begin{array}{c}\text { Age } \\
\text { (Years) }\end{array}$ & $\underset{(\mathrm{cm})}{\text { Height }}$ & $\underset{(\mathrm{kg})}{\text { Weight }}$ & Disease & $\begin{array}{c}\text { Prednisone } \\
\text { Dose (mg/day)* }\end{array}$ \\
\hline 1 & .. & & 63 & 146 & 78 & Chronic bronchitis & 15 \\
\hline $\begin{array}{l}2 \\
3 \\
4\end{array}$ & $\begin{array}{l}\ldots \\
\cdots\end{array}$ & $\begin{array}{l}. \\
\cdots\end{array}$ & $\begin{array}{l}48 \\
62 \\
61\end{array}$ & $\begin{array}{l}147 \\
147 \\
185\end{array}$ & $\begin{array}{l}85 \\
75 \\
86\end{array}$ & $\begin{array}{l}\text { with asthma } \\
\text { Asthma } \\
\text { Asthma } \\
\text { Asthma, sensitive }\end{array}$ & $\begin{array}{r}10 \\
4 \\
10\end{array}$ \\
\hline 5 & .. & .. & 62 & 150 & 75 & $\begin{array}{l}\text { Chronic bronchitis } \\
\text { with asthma }\end{array}$ & 15 \\
\hline
\end{tabular}

* All patients were also on beclomethasone and salbutamol aerosols.

TABLE II-FEV 1 and Forced Vital Capacity (FVC) with Predicted Normal Values before and after Bronchodilator $(200 \mathrm{\mu g}$ Salbutamol by Pressurized Aerosol) and Percentage Response in FEV 1 to Bronchodilator in Five Patients

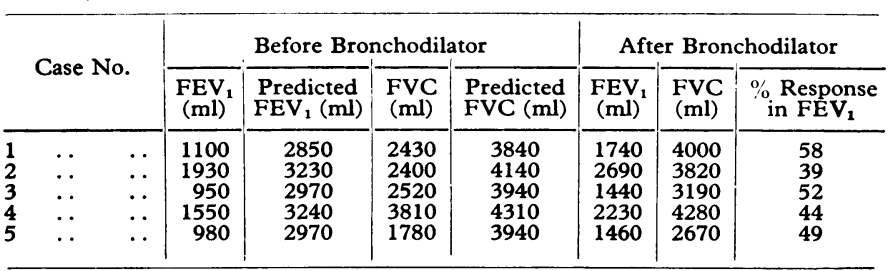

The single-blind randomised trial was conducted at the same time on seven separate days. All patients were in a steady state of moderate airways obstruction throughout, with no recent history of exacerbations of asthma or evidence of acute bronchial infection. Also there had to be less than $15 \%$ variation between the control values of forced expiratory volume in one second $\left(F E V_{1}\right)$ for each patient throughout the trial, and each control $\mathrm{FEV}_{1}$ had to be between $25 \%$ and $70 \%$ of predicted normal. All sympathomimetic drugs were withdrawn for 12 hours before each study, but oral and aerosol corticosteroids were continued at their maintenance doses.

Each drug was infused intravenously for one hour with a constant infusion pump (HR Flow Inducer, Watson-Marlow Ltd., England) into a left dorsal hand vein, with the patient seated upright. At the end of each infusion the same drug was inhaled from a pressurized aerosol. The treatments for the seven trial days were as follows: (a) rimiterol hydrobromide (Riker Laboratories) 0.2 (high dose), 0.1 (medium dose), and $0.05 \mu \mathrm{g} \mathrm{kg}^{-1} \mathrm{~min}^{-1}$ (low dose); pressurized aerosol $400 \mu \mathrm{g}(200 \mu \mathrm{g} / \mathrm{puff}) ;(b)$ salbutamol sulphate (Allen and Hanburys) $0 \cdot 1,0.05$, and $0.025 \mu \mathrm{g} \mathrm{kg}^{-1} \mathrm{~min}^{-1}$; pressurized aerosol $200 \mu \mathrm{g}(100 \mu \mathrm{g} /$ puff $) ;(c)$ placebo, $5 \%$ dextrose injection B.P. (Baxter); placebo pressurized aerosol ( 2 puffs). All treatments were made up to $100 \mathrm{ml}$ with $5 \%$ dextrose injection B.P.

Ventilatory response was determined by measuring the $F_{E V}$ with a dry spirometer (Vitalograph). The heart rate was taken from lead 2 of an E.C.G. and blood pressure with a mercury sphygmomanometer. Digital skeletal muscular tremor was measured 131417 using an accelerometer with tremor recorder and frequency analyser.

Resting baseline recordings of $\mathrm{FEV}_{1}$ (highest of three values as control), blood pressure, digital tremor, and heart rate over one minute were taken. After the start of each infusion $\mathrm{FEV}_{1}$ (best of two readings), blood pressure, and digital tremor were measured at 10, 20, 30, 45, and 60 minutes. A continuous E.C.G. was run throughout the first 10 minutes of the infusion and thereafter one-minute E.C.G. recordings were taken at $20,30,45$, and 60 minutes. All four values were measured 5, 15, and 30 minutes after the aerosol inhalation. Each time heart rate and digital tremor were recorded simultaneously first, then blood pressure, and lastly $\mathrm{FEV}_{1}$. The results were statistically analysed using the paired Student's $t$ test.

\section{Results}

\section{RESPIRATORY STUDIES}

Ventilatory response was expressed as the percentage change in FEV from the control value. There was no significant difference between the control $F E V$, values before each treatment. The $F E V_{1}$ rise during rimiterol infusions was significantly greater than the change after placebo at all times (fig. $1 ; \mathrm{P}<0.05$ ). Though the mean peak increases in $\mathrm{FEV}_{1}$ with rimiterol occurred at 60 minutes the $\mathrm{FEV}_{1}$ response seemed to level out after 30 minutes, with less than $5 \%$ improvement during the second half of the infusion. There was no significant difference between the $\mathrm{FEV}_{1}$ increases at 10 and 60 minutes. FEV improved significantly during the salbutamol infusions but only after the medium and high doses (fig. 2; $\mathrm{P}<0.05$ ). The mean peak FEVI increases with salbutamol occurred at 45 minutes with the medium dose and at 60 minutes with low and high doses. Though FEV $_{1}$ response reached a plateau after 45 minutes with salbutamol medium dose it was still increasing with the low and high doses at 60 minutes. There was a significant increase in $\mathrm{FEV}_{1}$ from 10 to 60 minutes with salbutamol medium $(P<0.01)$ and high $(P<0.05)$ doses. After the drug aerosol inhalations there were further significant $\mathrm{FEV}_{1}$ increases compared with the 60 minute values $(P<0.05)$. There were significant falls in $\mathrm{FEV}_{1}$ from 5 to 30 minutes after the aerosol with rimiterol $(\mathrm{P}<0.05)$.

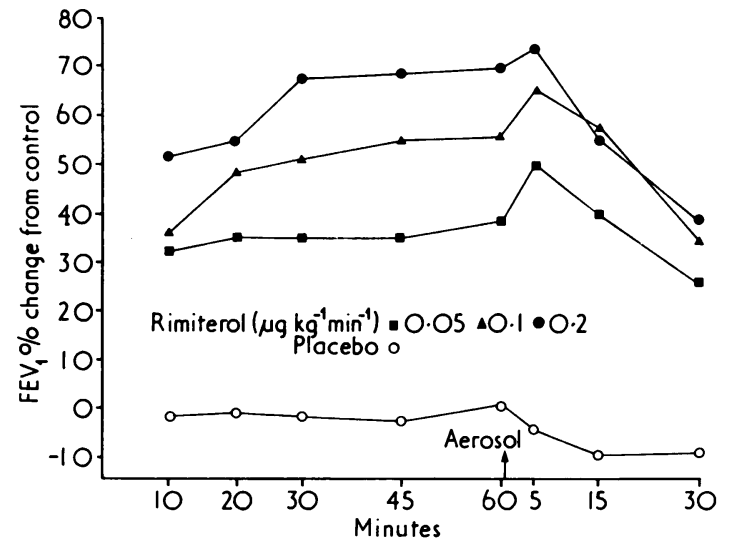

FIG. 1-Mean percentage changes in $\mathrm{FEV}_{1}$ from control values in five asthmatic patients during 60 -minute intravenous infusions of rimiterol and placematic patients during 60 -minute intravenous infusions of rimiterol and place-
bo and for 30 minutes after inhalation of rimiterol $(400 \mu \mathrm{g})$ or placebo by bo and for 30 minutes
pressurized aerosols.

As an expression of the total effect of each drug the areas $\left(F E V_{1}\right.$ 
integrated responses) under the FEVI response curves according to time were calculated during various periods for each patient (table III). Only the area for high-dose rimiterol was significantly greater than high-dose salbutamol during all infusion periods $(\mathrm{P}<0.05)$.

\section{CARDIOVASCULAR STUDIES}

The mean rise in heart rate with rimiterol infusions was significantly greater than the change after placebo from 30 minutes $(P<0.05)$, 10 minutes $(P<0.02)$, and 5 minutes $(P<0.01)$ with the low, medium, and high doses respectively, and all the mean peak increases occurred at 45 minutes (fig. 3). The tachycardia with each dose seemed to level out after 30 minutes though there was a significant difference between the heart rate increase at 10 and 60 minutes after the high dose $(P<0.05)$. During salbutamol infusions significant mean heart rate rises compared to the change after placebo occurred from 45 minutes, $(P<0.05), 5$ minutes $(P<0.02)$, and 10 minutes $(P<0.01)$ for the low, medium, and high doses respectively (fig. 4 ). The mean peak heart rate increases with salbutamol were observed at 10 minutes with low dose and 60 minutes with medium and high doses. With salbutamol medium and high doses the heart rate was still rising at 60 minutes and was significantly higher than at 10 minutes $(P<0.01)$. After the appropriate aerosol inhalations the heart rate declined, and at 30 minutes only high-dose rimiterol $(P<0.05)$ and medium-dose $(P<0.02)$ and high-dose $(P<0.05)$ salbutamol produced a significant increase compared with placebo.

TABLE III-Mean FEV $V_{1}$ and Heart Rate Integrated Responses for Five Patients during 0-30 Minute, 30-60 Minute, and 0-60 Minute Infusion Periods and 0-30 Postinfusion Period. Integrated Responses s.ere Calculated Areas under $F E V_{1}$ and Heart Rate Response Curves with Respect to Time after Start of Intravenous Infusion and after Aerosol Inhalation

\begin{tabular}{|c|c|c|c|c|c|}
\hline \multirow{2}{*}{ Treatment } & \multirow{2}{*}{ Dose } & \multicolumn{3}{|c|}{ Infusion } & \multirow{2}{*}{$\begin{array}{l}\text { After Infusion } \\
0-30 \mathrm{~min}\end{array}$} \\
\hline & & $0-30 \mathrm{~min}$ & $30-60 \mathrm{~min}$ & $0-60 \mathrm{~min}$ & \\
\hline \multicolumn{6}{|c|}{$F E V_{1}$ Integrated Response } \\
\hline $\begin{array}{l}\text { Rimiterol } \\
\text { Salbutamol } \\
\text { Placebo }\end{array}$ & $\begin{array}{l}\text { Low } \\
\text { Medium } \\
\text { High } \\
\text { Low } \\
\text { Medium } \\
\text { High }\end{array}$ & $\begin{array}{c}852^{* *} \\
1101^{* *} \\
1407^{* * *} \\
302 \\
587^{* *} \\
1065^{* *} \\
-32\end{array}$ & \begin{tabular}{|l|}
$1068^{* *}$ \\
$1623^{* *}$ \\
$2069^{* * *}$ \\
560 \\
$1091^{* * *}$ \\
$1568^{* * *}$ \\
-41
\end{tabular} & $\begin{array}{c}1920^{* *} \\
2724 * * \\
3476^{* * *} \\
862 \\
1678^{* * *} \\
2633^{* *} \\
-73\end{array}$ & $\begin{array}{l}1038^{* * *} \\
1605^{* *} \\
1694^{* * *} \\
1234^{* *} \\
1498^{* * *} \\
1926^{* *} \\
-202\end{array}$ \\
\hline \multicolumn{6}{|c|}{ Heart Rate Integrated Response } \\
\hline $\begin{array}{l}\text { Salbutamol } \\
\text { Placebo }\end{array}$ & $\begin{array}{l}\text { Low } \\
\text { Medium } \\
\text { High } \\
\text { Low } \\
\text { Medium } \\
\text { High }\end{array}$ & $\begin{array}{c}95 \\
250^{* *} \\
424^{* * *} \\
77 \\
148^{* *} \\
310^{* * *} \\
-5\end{array}$ & \begin{tabular}{|c}
$127^{* * *}$ \\
$341^{* * *}$ \\
$639^{* * *}$ \\
$52 *$ \\
$274^{* * * *}$ \\
$539 * * *$ \\
-99
\end{tabular} & $\begin{array}{c}222^{*} \\
590^{* * *} \\
1063^{* * *} \\
129 \\
423^{* * *} \\
848^{* * *} \\
-104\end{array}$ & $\begin{array}{c}-12^{*} \\
152^{*} \\
304^{* *} \\
-31 \\
175^{* * *} \\
418^{* * *} \\
-141\end{array}$ \\
\hline
\end{tabular}

Comparison with Placebo (paired Student's $t$ test): $* P<0.05$. *** P<0.02.

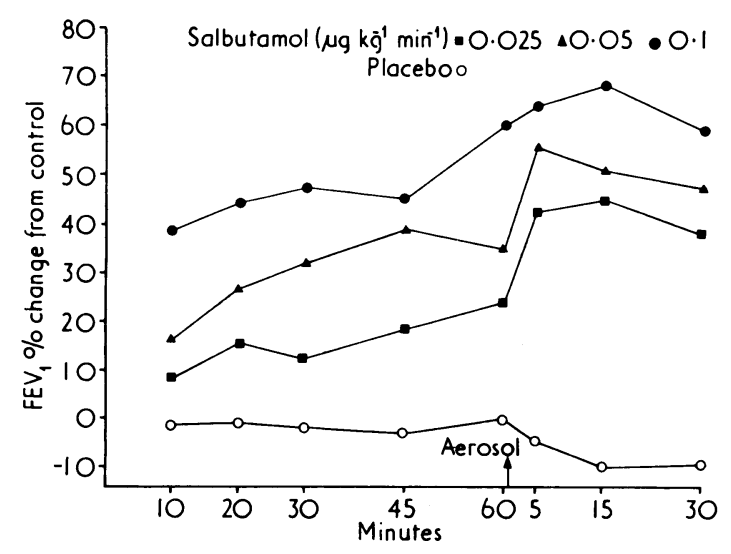

FIG. 2-Mean percentage changes in $\mathrm{FEV}_{1}$ from control values in five asthmatic patients during 60-minute intravenous infusions of salbutamol and placebo and for 30 minutes after inhalation of salbutamol $(200 \mu \mathrm{g})$ or placebo by pressurized aerosols.

The areas (heart rate integrated responses) under the heart rate response curves according to time were calculated for each patient during various periods (table III). There were no significant differences between the areas for the corresponding doses of each drug during any period. No patient complained of palpitations and there were no E.C.G. abnormalities detected during the study.

The changes in pulse pressure from control for each patient were averaged for the $0-30$ minute and $30-60$ minute infusion periods and the 0-30 minute postinfusion period. The mean peak increases in pulse pressure for all the patients were dose-related and occurred during the 30-60 minute infusion period. On rimiterol the increases ranged from 8.4 to $20.4 \mathrm{~mm} \mathrm{Hg}$ and on salbutamol doses from 5.5 to $23.1 \mathrm{~mm} \mathrm{Hg}$; on placebo the increase was $0.2 \mathrm{~mm} \mathrm{Hg}$. Some mean increases with rimiterol were significantly greater than the change after placebo for the $0-30$ minute infusion period (all doses $P<0.01$ ), 30-60 minute infusion period (medium dose $P<0.01$, high dose, $P<0.02$ ), and the postinfusion period (medium dose $P<0.02$ ). Similarly with salbutamol some mean increases were significantly greater than the change after placebo for both infusion periods (medium dose $\mathrm{P}<0.02$, high dose $\mathrm{P}<0.01$ ) and for the postinfusion period (high dose $P<0.01$ ). There were no significant differences in pressure between the corresponding doses of each drug for any period.

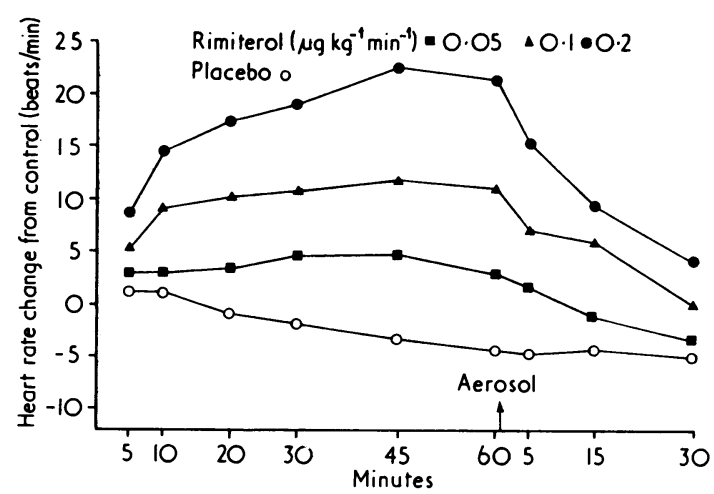

FIG. 3-Mean changes in heart rate from control values in five asthmatic patients during 60 -minute intravenous infusions of rimiterol and placebo and for 30 minutes after inhalation of rimiterol $(400 \mu \mathrm{g})$ or placebo by pressurized aerosols.

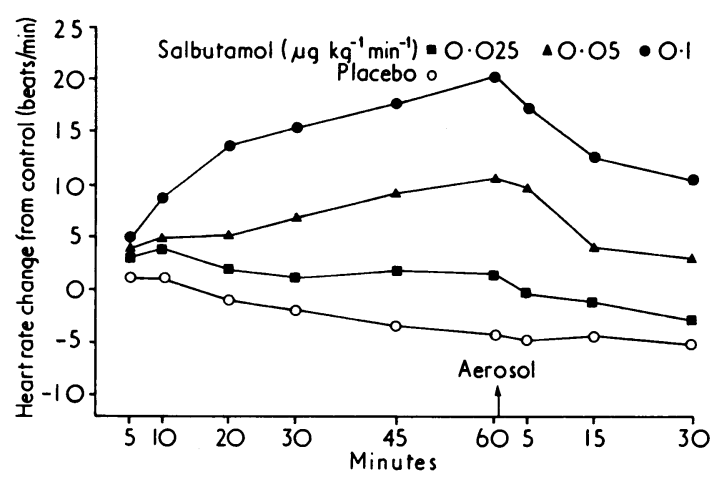

FIG. 4-Mean changes in heart rate from control values in five asthmatic patients during 60-minute intravenous infusions of salbutamol and placebo and for 30 minutes after inhalation of salbutamol $(200 \mu \mathrm{g})$ or placebo by pressurized aerosols.

\section{TREMOR STUDIES}

Control amplitude of tremor varied widely among the patients. The increases in tremor were expressed as the percentage changes in the amplitude of tremor from the control values. These percentage changes were averaged for each patient for the 0-30 minute and 30-60 minute infusion periods and the $0-30$ minute postinfusion period. The mean peak increases in tremor for all the patients during the infusion periods on rimiterol ranged from 71 to $153 \%$, on salbutamol from 29 to $74 \%$, and on placebo a reduction of $15 \%$ occurred. Only the mean increases with rimiterol high dose (all periods), salbutamol medium (30-60 minute infusion and 0-30 minute postinfusion) and high doses (both infusion periods) were significantly greater than the change after 
placebo $(P<0.05)$. There were no significant differences between the corresponding doses of each drug for any period. The subjective sensation of tremor in the outstretched hand while measurement was in progress was reported during the infusions of medium-dose (two patients) and high-dose (three) rimiterol and medium-dose (two) and high-dose (two) salbutamol. These symptoms did not correlate well with the recorded amplitude of tremor. No patient complained of generalized tremor.

\section{Discussion}

Studies with single equimolar intravenous injections of isoprenaline, salbutamol, and rimiterol in healthy people with histamine-induced bronchoconstriction ${ }^{13}$ and asthmatic patients ${ }^{14}$ have shown that for equal bronchodilatation isoprenaline increased the heart rate two and two and a half times more, respectively, than rimiterol and salbutamol. The duration of action of rimiterol is short, which confirms that it has a short half life like that of isoprenaline ${ }^{15}$ and unlike that of salbutamol. ${ }^{18}$ Effective bronchodilatation with rimiterol and salbutamol was accompanied by heart rate increases of greater than 20 beats $/ \mathrm{min}$ Sinus tachycardia greater than 120 beats/min, hypoxaemia, and respiratory acidosis commonly occur in patients with severe asthma. ${ }^{1519}$ In these studies the tachycardia was unrelated to the nature of preceding treatment and diminished with clinical improvement despite frequent use of large doses of sympathomimetic drugs. Any major increase in tachycardia produced by treatment might result in cardiac dysrhythmias, particularly in the presence of hypoxaemia and respiratory acidosis. Studies with hypoxic dogs have shown that the cardiac effects of isoprenaline, orciprenaline, and salbutamol were increased by severe hypoxia. ${ }^{20} 21$

Of the $\beta$-adrenoceptor stimulating drugs only isoprenaline has been described for intravenous therapy in severe asthma, ${ }^{22}$ and relatively good tolerance to the tachycardias produced by large doses was shown in children when adequate oxygenation was ensured. It is desirable, however, that bronchodilator treatment should produce minimal cardiac stimulation, so we assessed the effects of rimiterol and salbutamol-selective $\beta_{2}$-adrenoceptor stimulating drugs-in asthmatic patients by constant low dose intravenous infusions. The three doses of each drug were selected according to the results of previous studies. 1314

Both drugs produced and maintained effective dose-related bronchodilatation during the one-hour intravenous infusions. Because of its short half life rimiterol produced peak bronchodilatation within the hour, but salbutamol might need longer for its full respiratory effect to be manifest. We assessed the possibility of the development of resistance because of prolonged sympathetic stimulation by the response to the prescribed dose of each drug by pressurized aerosol at the end of each infusion. Rebound bronchoconstriction has been observed during bronchodilator trials, ${ }^{713142324}$ and patients have become refractory to excessive doses of adrenergic drugs until their withdrawal. 25-27 Metabolites of $\beta$-adrenoceptor agonists with weak $\beta$-adrenoceptor antagonistic properties 2829 and resistance to the natural adrenergic transmitter ${ }^{30}$ have been suggested as possible causes of these phenomena. Studies in animals ${ }^{31}$ and $\operatorname{man}^{32-35}$ have failed to confirm resistance to the respiratory effects of $\beta$-adrenoceptor agonists. We found no evidence of bronchial resistance resulting from the one-hour infusions. A similar $\mathrm{FEV}_{1}$ increase after the drug aerosol inhalations, until the patients reached near-maximal bronchodilatation, was observed regardless of the dose of the preceding infusion. It should be emphasized that patients with severe asthma might initially be more refractory to this treatment than our patients, who were very responsive though they often showed the need for treatment at the start of a study because of increasing wheeze and dyspnoea.

The heart rate reached equilibrium earlier during rimiterol infusions and declined more rapidly after they had stopped, which showed its shorter duration of action. A longer infusion time is needed to determine the maximal heart rate attainable with salbutamol. There was great individual variation in the peak heart rate increases, ranging from 12 to 30 beats/min with the high doses but always less than 10 beats/min with the low doses of each drug. These results indicate that in an individual patient effective bronchodilatation may be produced with minimal heart rate increases.

The dose-related increases in pulse pressure with the lower doses of each drug were unlikely to be significant, though their effects on pulsus paradoxus, which often occurs in severe asthma, ${ }^{5}$ are unknown. We saw no evidence of cardiovasulcar resistance during the drug infusions. Cardiovascular resistance to prolonged sympathetic stimulation by $\beta$-adrenoceptor agonists has been observed in animals ${ }^{30}{ }^{36-38}$ and man, ${ }^{28} 30$ but other workers have failed to show such resistance. ${ }^{33} 39$

Both the individual control amplitude of tremor and the post-treatment increases were variable. Also, during the infusions the level of tremor varied, but with all doses the symptoms were generally minimal and unlikely to be troublesome with the thurapeutic doses envisaged.

Constant intravenous infusions provide predictable drug concentrations in the blood and at the receptor sites. When the drug has a short half life blood concentration equilibrium will be reached rapidly and maintained precisely by a constant infusion enabling accurate monitoring. Woolcock and Read ${ }^{40}$ have shown that $\mathrm{FEV}_{1}$ may be an unreliable guide in assessing early improvement in patients with severe asthma associated with marked lung hyperinflation. Thus, the drug dose should be monitored by the heart rate change in the individual patient. Cooke et al. ${ }^{41}$ have shown that the tachycardia after rimiterol administered by I.P.P.V. was less in magnitude and duration than after salbutamol and suggested that rimiterol may become the bronchodilator of choice for I.P.P.V. treatment in asthma. Further studies are in progress to assess rimiterol intravenous infusions over longer periods with particular reference to selectivity and resistance. If our findings are confirmed rimiterol may prove to be a valuable bronchodilator for intravenous treatment in severe asthma either alone or in combination with rimiterol by I.P.P.V.

G.E.M. thanks the Postgraduate Medical Foundation administered by the Postgraduate Committee in Medicine, the University of Sydney, for their financial support. We thank Dr. N. C. Oswald, consultant physician at St. Bartholomew's Hospital, for his helpful advice and permission to study patients under his care, the Board of Governors of St. Bartholomew's Hospital for financial assistance towards cost of equipment, Mr. R. W. Howell for statistics, Riker Laboratories for supplying rimiterol, and Allen and Hanburys Ltd. for salbutamol.

\section{References}

1 Rees, H. A., Millar, J. S., and Donald, K. W., Quarterly fournal of Medicine,

1968, 61, 541.
2 Crofton, J., and Douglas, A., Respiratory Diseases, p. 419. Oxford, Blackwell, 1969.

3 Grant, I. W. B., Tubercle, 1971, 1, 43.

4 Jones, E. S., Proceedings of the Royal Socioty of Medicine, 1971, 64, 1151.

5 Rebuck, A. S., and Read, J., American Fournal of Medicine, 1971, 51, 788.

6 Warrell, D. A., et al., British Medical Fournal, 1970, 1, 65.

Paterson, J. W., Courtenay Evans, R. J., and Prime, F. J., British fournal of Diseases of the Chest, 1971, 65, 21.

${ }^{8}$ Svedmyr, N., and Thiringer, G., Postgraduate Medical fournal, 1971, 47, Suppl. p. 44

Svedmyr, N., Malmberg, R., and Thiringer, G., Scandinavian fournal of Respiratory Diseases, $1972,53,302$.

${ }^{10}$ Thiringer, G., Bergh, N. P., and Svedmyr, N., Scandinavian fournal of Respiratory Diseases, 1971, 52, 183.

11 McEvoy, J. D. S., Vall-Spinosa, A., and Paterson, J. W., American Review of Respiratory Diseases, 1973, 108, 490.

12 Smith, A. P., British fournal of Clinical Pharmacology, 1974, 1, 399.

13 Marlin, G. E., and Turner, P., British fournal of Clinical Pharmacology, $1975,2,41$.

14 Marlin, G. E., and Turner, P., International fournal of Clinical Pharmacology, Therapy and Toxicology, in press.

15 Griffin, J. P., Williams, J. R. B., and Maughan, E., Clinical Trials fournal, $1973,10,13$.

16 Ciba Guest Symposium Report, Thorax, 1959, 14, 286. 
17 Watson, J. M., and Richens, A., British fournal of Clinical Pharmacology, $1974,1,223$.

18 Walker, S. R., et al., Clinical Pharmacology and Therapeutics, 1972, 13, 861.

19 Tai, E., and Read, J., Lancet, 1967, 1, 644.

20 Collins, J. M., et al., British fournal of Pharmacology, 1969, 36, 35.

21 Shanks, R. G., and Swanton, J. G., Proceedings of the European Society for the Study of Drug Toxicity, 1971, 12, 147.

for the Study of Drug Toxicity, 1971, 12, 147.
22 Wood, D. W., et al., fournal of Allergy, 1972, 50, 75.

23 Freedman, B. J., Meisner, P., and Hill, G. B., Thorax, 1968, 23, 590

24 Riding, W. D., Dinda, P., and Chatterjee, S. S., British fournal of Diseases of the Chest, 1970, 64, 37.

of the Chest, 1970, 64, 37.
Keighley, J. F., Annals of Internal Medicine, 1966, 65, 985.

${ }_{26}^{25}$ Keighley, J. F., Annals of Internal Medicine, 1966, 65, 985.

27 Van Metre, T. E., Fournal of Allergy, 1969, 43, 101

28 Paterson, J. W., et al., Lancet, 1968, 2, 426.

29 Hornsey, P. A., et al., Archives Internationales de Pharmacodynamie et de Therapie, 1971, 191, 357.

30 Conolly, M. E., et al., British fournal of Pharmacology, 1971, 43, 389.
${ }^{31}$ Pun, L-Q., McCulloch, M. W., and Rand, M. J., European Fournal of Pharmacology, 1971, 14, 140.

32 Gibson, J., and Tattersfield, A. E., Bulletin de Physio-Pathologie Respiratoire, $1972,8,657$.

${ }^{33}$ Lichterfeld, A., and Lollgren, H., European fournal of Clinical Pharmacology, 1974, 7, 347.

34 Sims, B. A., British fournal of Clinical Pharmacology, 1974, 1, 291.

35 Svedmyr, N., Larsson, S., and Thiringer, G., Scandinavian fournal of Respiratory Diseases, 1974,88 , Suppl. p. 58.

36 Walz, D. T., Koppanyi, T., and Maengwyn-Davies, G. D., Fournal of Pharmacology and Experimental Therapeutics, 1960, 129, 200.

37 Butterworth, K. R., British fournal of Pharmacology, 1963, 21, 378.

38 Atkinson, J. M., and Rand, M. J., fournal of Pharmacy and Pharmacology, 1968, 20, 916 .

${ }^{39}$ Kingsley, P. J., Littlejohns, D. W., and Prichard, B. N. C., British Fournal of Pharmacology, 1972, 46, 539P.

0 Woolcock, A. J., and Read, J., American fournal of Medicine, 1966, 41, 259.

41 Cooke, N. J., et al., British Medical fournal, 1974, 1, 250.

\title{
Influence of Heredity and Environment in Determination of Skinfold Thickness in Children
}

\author{
C. G. D. BROOK, R. M. C. HUNTLEY, JOAN SLACK
}

British Medical fournal, 1975, 2, 719-721

\section{Summary}

Triceps and subscapular skinfold thicknesses were measured in 222 pairs of like-sex twins ( 78 monozygotic and 144 dizygotic) aged 3-15 years. Log transformations of the measurements were standardized for age and sex and the results used to estimate heritability - that is, the proportion of total variation determined by genetic factors. The overall contribution of non-genetic familial effects was small. There were appreciable differences in heritability between limb and trunk fat and between the sexes and at different ages. Over the age of 10 heritability was high for both sites in boys and girls. In younger children environmental factors contributed more to the variation.

\section{Introduction}

The separation of heredity and environment in the determination of body fat has proved difficult for want of suitable material and sufficient data. The use of weight alone to measure fatness in humans is uninformative, and weight-for-height indices do little to improve the information because of the large differences in body proportions between people of the same height and sex. Skinfold thicknesses correlate well with total body fat in both adults $^{1}$ and children. ${ }^{2}$

One study of monozygotic twins brought up together and apart depended only on measurement of weight. ${ }^{3}$ Another reported parent/child correlation coefficients of weight and skinfold thickness in children up to the age of 7 years; for weight

Department of Paediatrics, Middlesex Hospital, London W1N 8AA C. G. D. BROOK, M.D., M.RC.P., Consultant Paediatrician

Institute of Child Health, London WC1N 1 EH

R. M. C. HUNTLEY, PH.D., Senior Lecturer, Department of Development

JOAN SLACK, D.M., M.R.C.P., Scientific Officer, M.R.C. Clinical Genetics Unit a higher correlation was found for mother/child than for father/ child but for skinfold thickness the correlation coefficients were not significantly different from zero. ${ }^{4}$ On the other hand the correlations of skinfold thickness in adult twins suggested that genetic influences were strong but that the influence of sex, heredity, and environment differed for different sites. ${ }^{5}$

We report here the relative contribution of genetic and environmental factors to the variation of skinfold thickness in children of both sexes aged 3-15 years.

\section{Patients and Methods}

All twins registered at the Hospital for Sick Children, Great Ormond Street, aged 3-15 years who lived in Greater London were invited to take part. More twins were obtained through an appeal for volunteers at the end of a television programme about twins. ${ }^{\circ}$

Skinfold thicknesses were measured in the standard manner using a Harpenden skinfold caliper ${ }^{7}$ over the mid-point of the triceps muscle on the left arm (representative of limb fat) and under the angle of the left scapula (representative of trunk fat). Since skinfold thicknesses are distributed logarithmically in man, ${ }^{8} \log$-transformed scores were used throughout. During childhood the means and standard deviations of skinfold thickness change with age and sex; thus departures from the mean assume different importance at different ages, and standard deviation scores ${ }^{9}$ were therefore calculated in all cases using standard control values for each age and sex. ${ }^{10}$

Heritability, defined as the proportion of total variance of a characteristic in a particular population due to genetic causes, was calculated by three different methods from the correlation coefficients of skinfold thicknesses. If the variation of a characteristic is entirely genetically determined the correlation coefficient in monozygotic twins, who have all their genes in common, would be $1 \cdot 0$. In dizygotic twins, who have half their genes in common, the expected correlation coefficient would be 0.5 . Accordingly, the estimate of heritability is given by the correlation coefficient in monozygotic twins $\left({ }^{\mathrm{r}} \mathrm{MZ}\right)$, twice the correlation coefficient in dizygotic twins $\left({ }^{2} \mathrm{Dz}\right)$, or twice the difference between the correlation coefficients in monozygotic and dizygotic twins

TABLE I-Mean Standard Deviation Scores ( 1 S.E.) of Skinfold Thicknesses in Twins

\begin{tabular}{l|c|c|c}
\hline & $\begin{array}{c}\text { No. of } \\
\text { Pairs }\end{array}$ & $\begin{array}{c}\text { Triceps } \\
\text { Skinfold }\end{array}$ & $\begin{array}{c}\text { Subscapular } \\
\text { Skinfold }\end{array}$ \\
\hline $\begin{array}{l}\text { Monozygotic male twins } \\
\text { Dizygotic male twins }\end{array}$ & 38 & $-0.32 \pm 0.10$ & $-0.01 \pm 0.06$ \\
$\begin{array}{l}\text { Monozygotic female twins } \\
\text { Dizygotic female twins }\end{array}$ & 67 & $-0.28 \pm 0.09$ & $-0.14 \pm 0.06$ \\
& 70 & $-0.29 \pm 0.09$ & $-0.07 \pm 0.06$ \\
& 77 & $-0.24 \pm 0.07$ & $-0.06 \pm 0.05$ \\
\hline
\end{tabular}

